Вісник Дніпропетровського університету. Біологія. Екологія. - 2011. - Вип. 19, т. 2. - С. 3-12.

Visnyk of Dnipropetrovsk University. Biology. Ecology. - 2011. - Vol. 19, N 2. - P. 3-12.

УДК 598.115.33.06(477.4)

\author{
А. Л. Байбуз ${ }^{1}$, О. В. Кукушкин ${ }^{2}$, А. И. Зиненко ${ }^{3}$ \\ ${ }^{1}$ Кировоградский государственный педагогический университет им. Владимира Винниченко \\ ${ }^{2}$ Карадагский природный заповедник НАНУ \\ ${ }^{3}$ Харьковский национальный университет им. В. Н. Каразина
}

\title{
ТАКСОНОМИЧЕСКИЙ СТАТУС СТЕПНОЙ ГАДЮКИ ПРАВОБЕРЕЖНОЙ УКРАИНЫ
}

Приводятся материалы по морфологической изменчивости степной гадюки из Кировоградской области. С использованием многомерного анализа проведена предварительная оценка степени сходства изученной локальной группировки с популяциями Левобережной Украины и Крыма. Данные морфологии, наряду с полученными ранее результатами анализа митохондриальной ДНК, показывают, что данная популяция относится к широко распространенному в Евразии виду Vірега renardi (Christoph, 1861) и проявляет наибольшее морфологическое сходство с популяциями равнинного Крыма, Присивашья и Лесостепи Левобережной Украины. Это может указывать на сложную историю колонизации Правобережья степной гадюкой и влияние условий среды на морфологию.

\author{
А. Л. Байбуз ${ }^{1}$, О. В. Кукушкін ${ }^{2}$, О. І. Зіненко ${ }^{3}$ \\ ${ }^{1}$ Кіровоградський державний педагогічний університет ім. Володимира Винниченка \\ ${ }^{2}$ Карадазький природний заповідник НАНУ \\ ${ }^{3}$ Харківський національний університет ім. В. Н. Каразіна

\section{ТАКСОНОМІЧНИЙ СТАТУС СТЕПОВОЇ ГАДЮКИ ПРАВОБЕРЕЖНОЇ УКРАЇНИ}

\begin{abstract}
Наведено матеріали щодо морфологічної мінливості степової гадюки в Кіровоградській області. Із використанням багатовимірного аналізу проведено попередню оцінку ступеня подібності цього локального угрупування 3 популяціями Лівобережної України та Криму. Дані морфології разом 3 отриманими раніше результатами аналізу мітохондріальної ДНК свідчать, що ця популяція належить до широко розповсюдженого в Євразії виду Vipera renardi (Christoph, 1861) та демонструє найбільшу морфологічну подібність із популяціями рівнинного Криму, Присивашшя та Лісостепу Лівобережної України. Це може свідчити про складну історію колонізації Правобережжя степовою гадюкою та вплив умов середовища на морфологію.
\end{abstract}

\author{
A. L. Baybuz ${ }^{1}$, O. V. Kukushkin ${ }^{2}$, O. I. Zinenko ${ }^{3}$ \\ ${ }^{l}$ V. Vynnychenko Kirovohrad State Pedagogical University \\ ${ }^{2}$ Karadag Nature Reserve of NAS Ukraine \\ ${ }^{3}$ Museum of Nature, V. N. Karazin Kharkiv National University

\section{ON THE ISSUE OF TAXONOMICAL STATUS \\ OF STEPPE VIPER (VIPERA RENARDI) IN RIGHT-BANK UKRAINE}

Data on morphologic variability of the steppe viper in the Kirovograd region (Right-bank Ukraine) are given firstly. Tentative estimation of the similarity level of the local population and the populations from the Left-bank Ukraine and the Crimea was carried out using methods of the multivariate statistics. 
Morphological data in line with the results of mitochondrial DNA analysis show that the population in the Kirovograd region belongs to widespread Eurasian species Vipera renardi and morphologically most close to the original populations of the lowland Crimea, Sivash and Forest-Steppe of the Left-bank Ukraine. This could indicate the complicated history of the Right-bank Ukraine colonization by the steppe viper and possible influence of environmental conditions on the vipers' morphology.

\section{Введение}

Степная гадюка Vipera renardi (Christoph, 1861) в относительно недалеком прошлом была распространена по всей степной зоне Украины. Большая часть известных находок вида приходится на Левобережье и Крым $[8 ; 11 ; 12]$, но в первой половине $\mathrm{XX}$ века он отмечался многими исследователями и в Правобережье $[2 ; 4 ; 15 ; 16]$, хотя, по-видимому, изначально встречался здесь реже и был сравнительно немногочисленным [21]. В середине XX века, после интенсивного хозяйственного освоения степной зоны, численность степной гадюки в Правобережье снизилась катастрофически - во всяком случае, новые данные о ее находках практически перестали появляться. Наметилась тенденция считать этот вид в Правобережье практически вымершим [18]. Это мнение основывалось на отсутствии вполне достоверных находок гадюки на фоне повсеместного сокращения площади целинных степных участков ${ }^{1}$. Однако в последние десятилетия накопилось довольно много указаний на то, что степная гадюка к западу от Днепра все же могла сохраниться в окрестностях Николаева (устные сообщения А. А. Полищука и В. С. Марченко) и Кривого Рога (устное сообщение А. Н. Ярыгина), а также в некоторых других местах. В ряде случаев сведения о существовании локальных популяций степной гадюки в Правобережье находят свое подтверждение. Недавно опубликованы данные о находках вида в Компанеевском районе Кировоградской области [6] и на территории трех правобережных районов Днепропетровской области [3].

Вместе с тем, отсутствие сборов гадюк из Правобережья в коллекциях зоологических музеев Украины и России не позволяет однозначно отнести правобережные популяции к обитающей в Крыму и на Левобережье степной гадюке ( $V$. renardi) либо к равноудаленным популяциям молдавской луговой гадюки $V$. (u.) moldavica [27], в настоящее время распространенной преимущественно в Восточной Румынии, а в недалеком прошлом и на территории Молдовы $[20 ; 23 ; 24 ; 28]$ и относящейся к южноевропейской Vipera ursinii (Bonaparte, 1835).

Таксономический статус некоторых популяций, обитающих в непосредственной близости к границам Украины, до настоящего времени остается дискуссионным $[23 ; 27 ; 29 ; 30]$. Высказывалось даже мнение, что в румынской части дельты Дуная обитает еще не описанный таксон [31]. В связи с этим следует отметить, что в первой половине XX века предполагалось обитание в Правобережной Украине регионального «микроэндемика» - «V.r. occidentalis Mehely» [1; 21]. Изучение первоисточника [26] показало, что эти сведения в своей основе ошибочны: автор действительно различал «восточную» и «западную» формы $V$. renardi, однако это не влекло за собой каких бы то ни было таксономических выводов и, соответственно, не сопровождалось номен-

\footnotetext{
${ }^{1}$ Имеются основания считать, что резкое сокращение численности степной гадюки (вплоть до полного исчезновения в ряде районов) в 1980-х - начале 2000-х гг. произошло также в Северо-Западном Крыму (в том числе, на таких относительно слабо освоенных территориях как Тарханкутский п-ов [9] и приазовская часть Керченского п-ва). Не исключено, что наблюдающаяся в последние годы депрессия численности этого достаточно мезофильного вида змей в наиболее засушливых приморских местностях может быть обусловлена климатогенными факторами.
} 
клатурными изменениями. Характеристика «westlichen steppenform» приводилась по особям из бывшей Екатеринославской губернии (соответствует территориям нынешних Днепропетровской и Запорожской областей), а под «ostlichen steppenform» подразумевались гадюки из Узбекистана, впоследствии описанные [28] как подвид $V$. u. tienshanica. [16]. Базируясь на предложенных [26] габитуальных признаках (относительные размеры глаза, характер верхней поверхности морды), к «западной» форме Coluber renardi автор относил гадюк не только степной зоны нынешней Украины, но также Крыма, Северного Кавказа и Восточного Закавказья, к «восточной» - из степей юга Европейской России (включая северо-восток современной Украины) и Туркестана. Таким образом, название $V . r$. occidentalis, введенное в обиход в 1920-е годы [1;21], следует считать nomen nudum. Однако вопрос о систематической принадлежности степных гадюк Правобережья тем самым не снимается и по-прежнему остается актуальным, а их таксономический статус нуждается в уточнении.

\section{Материал и методы исследований}

Гадюк отлавливали в окрестностях с. Сасовка Компанеевского р-на Кировоградской обл. в 2008-2011 годах. Всего отловлено 10 взрослых особей (6 самцов и 4 самки).

Гадюки населяют степную балку длиной около 2,5 км, шириной 0,5 км, ориентированную с северо-востока на юго-запад. Растительность представлена разнотравнотипчаковой степью с участием ковыля-волосатика (Stipa capillata), астрагала шерстистоцветкового (Astragalus dasyanthus), прострела чернеющего (Pulsatilla nigricans). По периметру балка оконтурена лесополосой из вяза, ясеня, робинии, клена. В балке ведется умеренный выпас (около полусотни голов крупного рогатого скота); изредка в весеннее время наблюдаются палы. Находящийся рядом в продолжении той же самой балки военный полигон испытывает еще меньшее влияние хозяйственной деятельности человека. Дополнительное описание местообитания можно найти в статье В. В. Гулая [6].

Морфологию змей описывали, используя комбинацию 19 признаков фолидоза, двух промеров и одного признака, характеризующего рисунок (табл. 1). Для характеристики билатеральных признаков фолидоза использовали средние арифметические значения признака справа и слева. Длины тела и хвоста измеряли с помощью рулетки, описание мелких черт фолидоза проводили с использованием бинокуляра или лупы.

В качестве сравнительных выборок использовали коллекции Музея природы ХНУ и змей из природных популяций. Выборки по географическому происхождению объединены в 6 групп (рис. 1). Кроме группы гадюк из Сасовки («Sasivka» на графиках) выделены следующие совокупности: в группу «Лесостепь» («Forest-Steppe») вошли особи с севера Луганской области, из Полтавской, Харьковской и Днепропетровской областей Украины, а также Белгородской области России (самцов - 32, самок 40); в группу «Юго-Восточная Украина» (S-E Ukraine) - особи с юга Луганской, Донецкой и Запорожской областей (самцов - 3, самок - 5); в группу «Присивашье» («Kherson-Sivash») - особи из Херсонской области и низменной северной части Крымского п-ва (самцов - 13, самок - 17); в группу «Равнинный Крым» (на графиках «Crimea») - особи из равнинных местообитаний в Крыму, главным образом, из окрестностей Феодосии (самцов - 27, самок - 18), в группу «Горный Крым» («Crimea, mountains») - особи из центральной части Главной гряды Крымских гор (самцов - 25, самок - 23), ранее описанные в качестве отдельного подвида - V. r. puzanovi Kukushkin, 2009 [13] (см. рис. 1).

Для статистической обработки использовали программу Статистика 7.0. Помимо описательной статистики применялся канонический дискриминантный анализ, кото- 
рый в данном случае служит для оценки степени общего сходства гадюк из изученной правобережной популяции с другими географически удаленными от нее популяциями. Этот вид анализа уместен в случае определения принадлежности популяций к той или иной сравнительной группе (подвиду, форме) и успешно применялся для анализа распространения пары близких таксонов ( $V$. b. berus Linnaeus, 1758 и V. b. nikolskii Vedmederja, Grubant et Rudaeva, 1986) в Правобережной Украине, Молдове и Румынии [33]. Ввиду существования у Viperidae значительного полового диморфизма в пропорциях тела и по признакам фолидоза, анализ проводили отдельно для самцов и самок. В дискриминантном анализе использовали 13 признаков (см. табл. 1), по которым обработано большинство выборок; прочие признаки использовали только для описания морфологии популяции из Сасовки.

Таблица 1

Признаки внешней морфологии при описании популяций V. renardi (по [13] с изменениями)

\begin{tabular}{|c|c|}
\hline Признак & Расшифровка признака \\
\hline Ventr.* & количество брюшных щитков \\
\hline S. cd.* & количество пар подхвостовых щитков \\
\hline Gul. & количество горловых чешуй \\
\hline Sq. $*$ & количество чешуй вокруг середины туловища \\
\hline Apicale* & количество апикальных щитков \\
\hline Lab.* & количество верхнегубных щитков \\
\hline Sub.* & количество нижнегубных щитков \\
\hline S. orb.* & количество чешуй вокруг глаза \\
\hline Inf. & количество нижнегубных щитков, касающихся I нижнечелюстного \\
\hline S. ic.* & количество интеркантальных \\
\hline S. ic. $1^{*}$ & количество предлобных щитков в первом ряду от лобного \\
\hline S. ic. $2 *$ & количество интеркантальных во втором и последующих рядах впереди от лобного \\
\hline S. pf. & количество парафронтальных (сумма с обеих сторон головы) \\
\hline S. sf. & количество щитков, одновременно касающихся лобного и надглазничного \\
\hline S. pn.* & количество щитков, касающихся заднего края носовых, не считая верхнего орбитального \\
\hline Lor.* & количество скуловых щитков \\
\hline S. ol.* & количество подглазничных орбитальных щитков, касающихся верхнегубных \\
\hline $\mathrm{ON}, \%$ & наличие контакта верхнего предглазничного орбитального и носового щитка \\
\hline Fpr, \% & фрагментация теменных щитков \\
\hline L., MM & длина тела \\
\hline L. cd., MM & длина хвоста \\
\hline $\mathrm{ZW}$ & количество зигзагообразных изгибов дорсомедиальной полосы \\
\hline
\end{tabular}

Примечание: * - использованные в дискриминантном анализе признаки.

Гадюки из Компанеевского р-на внешне представляют собой типичных степных гадюк из группы номинативного подвида $V$. r. renardi, на что указывают довольно большое количество брюшных и подхвостовых щитков, наличие 21 ряда вокруг середины тела, небольшое количество изгибов «зигзага», черные задние края верхнегубных щитков и т. д. (табл. 2). 


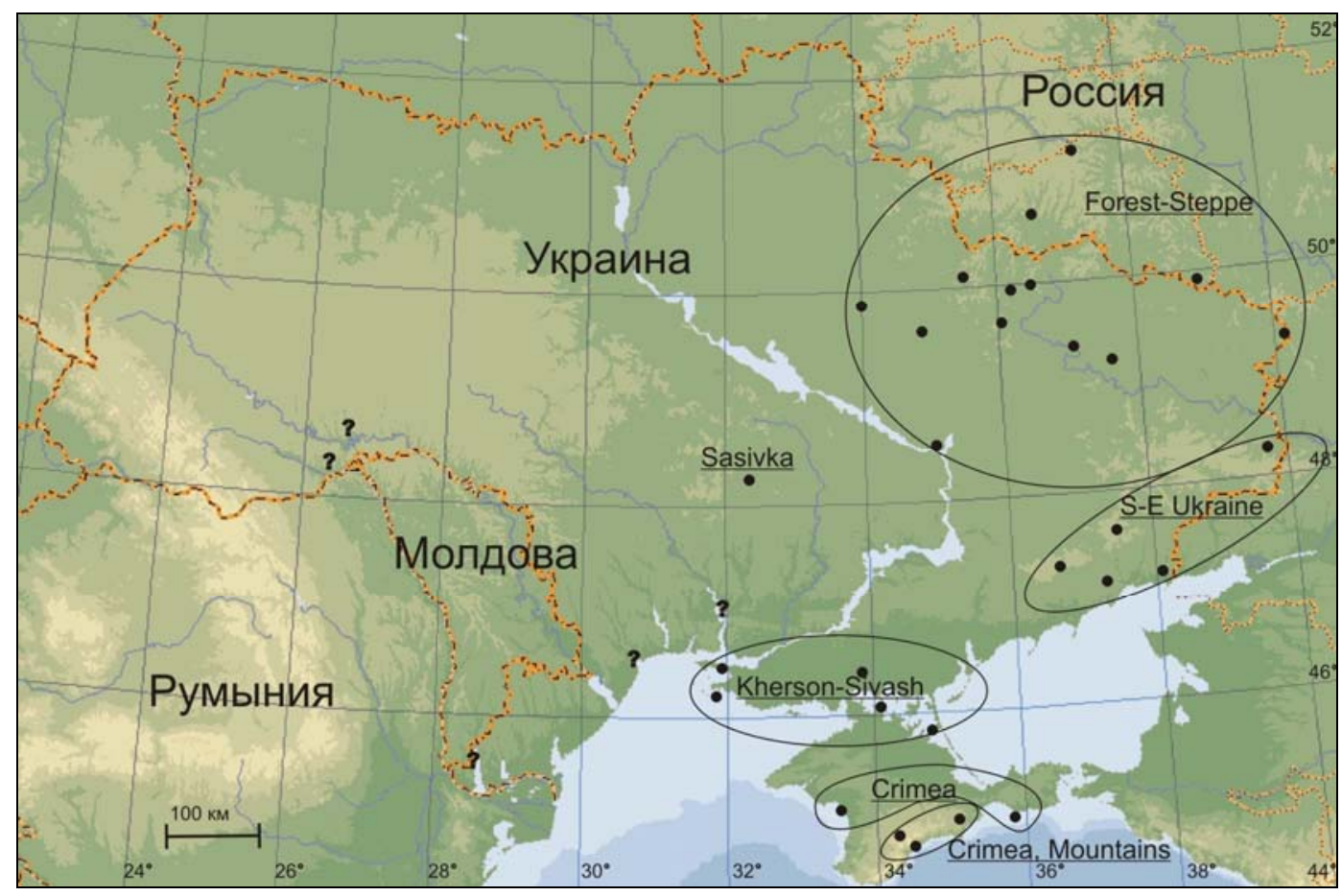

Рис. 1. Географическое положение изученных выборок $V$. renardi

\section{Результаты и их обсуждение}

Общая характеристика двух первых канонических корней дана в таблице 3. Наибольшее значение для разделения выборок гадюк в пространстве первых двух канонических корней имеют такие признаки щиткования головы как Lor., S. ic., S. ic. 1, S. ic. 2. Следующими идут количество брюшных щитков Ventr., подхвостовых щитков S. cd. (у самок). Признаки, описывающие изменчивость щиткования боковой поверхности головы или стабильные в пределах подвида V. renardi (Sq., Apicale), имеют очень небольшое значение для разделения популяций в анализе.

Графическое представление распределения сравнительных выборок в целом сходно для самцов и самок и согласуется с предыдущими попытками представить взаимоотношение украинских популяций степной гадюки с помощью анализа главных компонент [25]. Своеобразными полюсами изменчивости в Украине выступают горнокрымские популяции с одной стороны и популяции Левобережной Лесостепи и Степи с другой; змеи из Крымского Присивашья и Черноморского заповедника (Херсонская область) также обладают набором признаков, которые определяют их специфическое положение относительно двух предыдущих выборок.

Самцы из Сасовки на графике показывают почти полное перекрывание с выборками из Юго-Восточной Украины и Северной Лесостепи. Самки, однако, демонстрируют большее сходство с равнинными крымскими и присивашскими популяциями три из четырех особей находятся на графике в зоне перекрывания крымской и херсонско-присивашской выборок (рис. 2). Мы не пытаемся сравнивать наши данные с единственным опубликованным описанием степной гадюки из Правобережья [18], так как автор ошибочно принял бывший Александровский уезд за территорию, расположенную на Правобережье г. Александрия Кировоградской обл., хотя на самом деле последней соответствует левобережная часть современной Запорожской области. 
Гадюки из Сасовки разительно отличаются от $V$. u. moldavica по одному из основных диагностических признаков фолидоза - количеству рядов чешуй вокруг середины тела (табл. 2).

Морфологическая характеристика гадюк из Сасовки Компанеевского р-на Кировоградской обл. (обозначения признаков как в табл. 1)

\begin{tabular}{|c|c|c|}
\hline Признак & Самцы $(n=6)$ & Самки $(n=4)$ \\
\hline Ventr. & $143,83 \pm 0,54(142-146)$ & $144,50 \pm 1,32(141-147)$ \\
\hline S. cd. & $35,00 \pm 1,316(29-38)$ & $28,25 \pm 0,752(26-29)$ \\
\hline Gul. & $4,25 \pm 0,250(3,5-5,0)$ & $4,75 \pm 0,25(4,0-5,0)$ \\
\hline Sq. & $20,83 \pm 0,16(20-21)$ & $21,00 \pm 0,00(21)$ \\
\hline Lab. & $9,00 \pm 0,22(8,5-10,0)$ & $9,37 \pm 0,23(9,0-10,0)$ \\
\hline Sub. & $9,91 \pm 0,20(9,0-10,5)$ & $10,25 \pm 0,25(10,0-11,0)$ \\
\hline S. orb. & $8,75 \pm 0,21(8,0-9,5)$ & $9,00 \pm 0,20(8,5-9,5)$ \\
\hline Inf. & $4,00 \pm 0,00(4,0)$ & $4,00 \pm 0,00(4,0)$ \\
\hline S. ic. & $4,50 \pm 0,56(3-7)$ & $5,00 \pm 0,57(4-6)$ \\
\hline S. ic. 1 & $2,83 \pm 0,16(2-3)$ & $3,00 \pm 0,00(3)$ \\
\hline S. ic. 2 & $1,66 \pm 0,61(0-4)$ & $1,75 \pm 0,47(1-3)$ \\
\hline S. pf. & $4,16 \pm 0,73(2-7)$ & $4,62 \pm 1,14(2-7)$ \\
\hline S. sf. & $2,00 \pm 0,12(1,5-2,5)$ & $1,75 \pm 0,32(1,0-2,5)$ \\
\hline S. pn. & $2,75 \pm 0,17(2,0-3,0)$ & $2,75 \pm 0,25(2,0-3,0)$ \\
\hline Lor. & $3,83 \pm 0,35(2,5-4,5)$ & $4,75 \pm 0,43(4,0-6,0)$ \\
\hline S. ol. & $2,00 \pm 0,12(1,5-2,5)$ & $2,12 \pm 0,42(1,0-3,0)$ \\
\hline Apicale & $1,00 \pm 0,0(1)$ & $1,00 \pm 0,00(1)$ \\
\hline $\mathrm{ON}, \%$ & $\begin{array}{c}\text { не прикасается - } 50 \text { \% } \\
\text { прикасается с одной стороны - 16,7 \% } \\
\text { прикасается с двух сторон - 33,3\% }\end{array}$ & $\begin{array}{c}\text { не прикасается - } 0 \text { \% } \\
\text { прикасается с одной стороны }-25,0 \text { \% } \\
\text { прикасается с двух сторон }-75,0 \%\end{array}$ \\
\hline Fpr, \% & не фрагментированы - 100 \% & $\begin{array}{c}\text { не фрагментированы - } 50 \text { \% } \\
\text { фрагментированы с одной стороны - } 25 \% \\
\text { фрагментированы с двух сторон }-25 \%\end{array}$ \\
\hline L., MM & взрослые $(n=5)$ 427,6 $\pm 27,2(365-507)$ & $510,0 \pm 21,6(470-570)$ \\
\hline L. cd., MM & взрослые $(n=5)$ 65,4 $\pm 3,5(55-74)$ & $57,5 \pm 5,9(40-65)$ \\
\hline ZW & $66,0 \pm 0,0(66)$ & $56,7 \pm 1,3(54,0-58,0)$ \\
\hline
\end{tabular}

Таблица 3

Общая характеристика двух первых канонических корней дискриминантной функции

\begin{tabular}{|c|c|c|c|c|}
\hline \multirow{2}{*}{ Признак } & \multicolumn{2}{|c|}{ Самки } & \multicolumn{2}{c|}{ Самцы } \\
\cline { 2 - 5 } & Корень 1 & Корень 2 & Корень 1 & 0 Кень 2 \\
\hline Ventr. & 0,575 & 0,674 & 0,732 & $-0,504$ \\
\hline S. cd. & 0,438 & $-0,140$ & $-0,031$ & $-0,399$ \\
\hline Sq. & $-0,112$ & 0,222 & 0,233 & 0,405 \\
\hline Lab. & 0,139 & 0,207 & 0,332 & $-0,078$ \\
\hline Sub. & $-0,185$ & $-0,290$ & $-0,101$ & $-0,233$ \\
\hline S. orb. & 0,122 & $-0,176$ & 0,224 & $-1,852$ \\
\hline S. ic. & 1,738 & $-3,411$ & $-0,348$ & 0,309 \\
\hline S. pn. & 0,215 & 0,347 & 0,594 & $-0,781$ \\
\hline Lor. & 0,635 & $-0,881$ & $-0,344$ & 0,182 \\
\hline S. ol. & $-0,177$ & 0,121 & $-0,235$ & 0,143 \\
\hline Apicale & $-0,104$ & $-0,151$ & $-0,635$ & 1,067 \\
\hline S. ic. 1 & $-0,960$ & 1,334 & $-0,116$ & 1,505 \\
\hline S. ic. 2 & $-1,686$ & 3,715 & 0,358 & 0,480 \\
\hline Eigenval & 0,955 & 0,847 & 1,580 & 0,752 \\
\hline Cum.Prop & 0,395 & 0,745 & 0,576 & \\
\hline
\end{tabular}



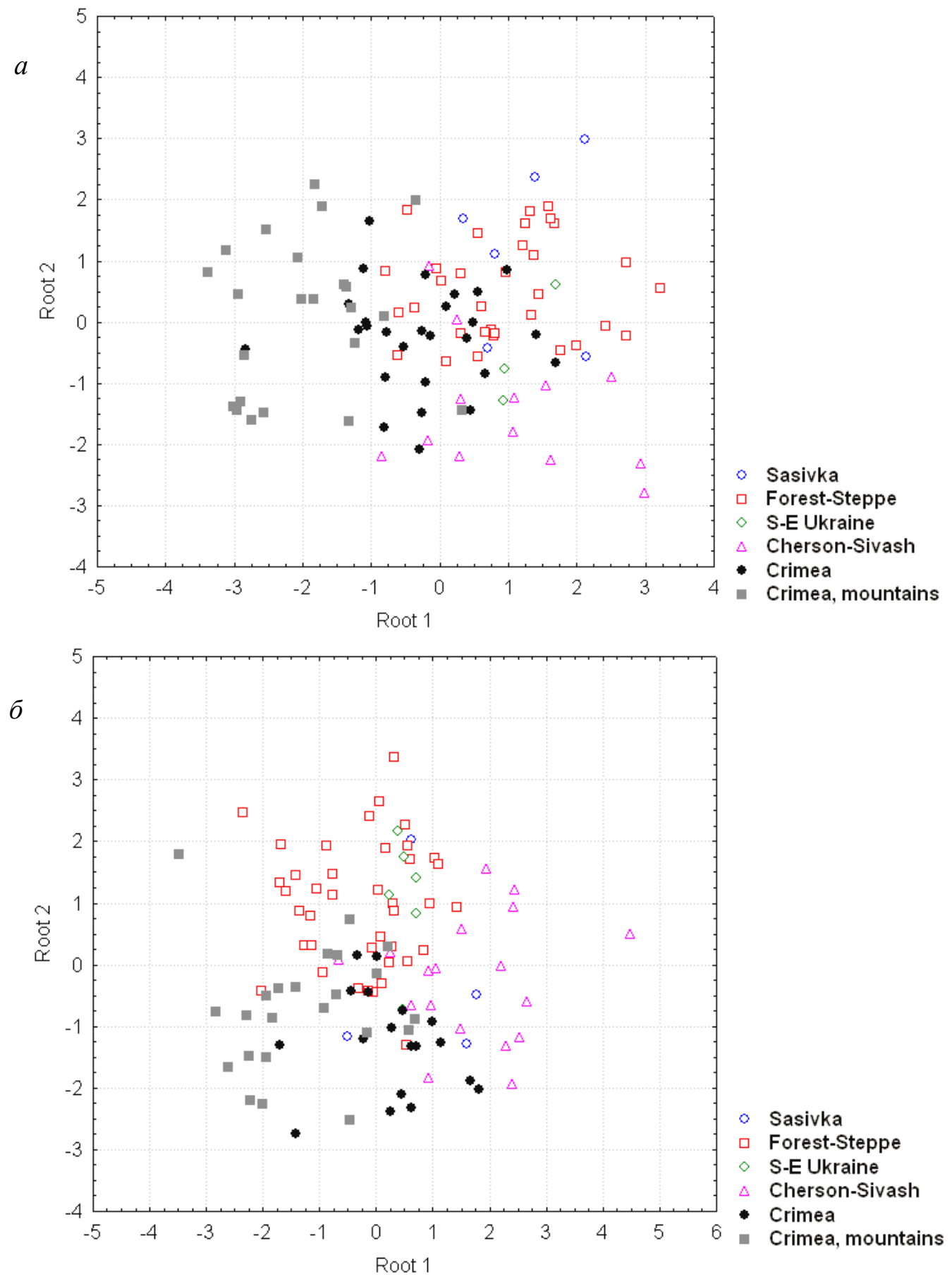

Рис. 2. Ординация на плоскости двух первых корней дискриминантной канонической функции гадюк из изученных популяций: $a$ - самцы, $\sigma$ - самки

Таким образом, с определенными оговорками относительно уровня знаний о систематике рода Vipera в первой половине XX века, можно считать, что вывод [19] о принадлежности степных гадюк со всей территории континентальной Украины к номинативной форме ( $V$. r. renardi) нашел свое подтверждение. $V$. ursinii пока в Украине 
не найдена. Предполагаемая граница между ареалами степной и молдавской луговой гадюк должна проходить западнее Кировограда, но восточнее территории Молдовы, или, по крайней мере, по р. Днестр. Ключевыми для ответа на вопрос о прохождении границы между $V$. ursinii и $V$. renardi могли бы стать данные о таксономической принадлежности популяций из Одесской и Черновицкой областей, где гадюки встречались в степных биотопах в прошлом и, возможно, сохранились до настоящего времени $[4 ; 7 ; 10$; $12 ; 15]$. Днепр, вопреки мнению некоторых исследователей [21], не является границей между родственными формами щиткоголовых гадюк - видами или подвидами.

По результатам молекулярного исследования (Зиненко и др., в печати), популяция из Сасовки неожиданно оказалась отнесена к митохондриальной гаплогруппе, распространенной преимущественно в Крыму. Следует заметить, однако, что данные только по митохондриальной ДНК из-за ее наследования по материнской линии и некоторых других особенностей [22; 32] малоинформативны для реконструкции истории популяции в случае ее гибридизации с близкородственными формами. Морфологические данные однозначно не подтверждают, однако и не опровергают возможное проникновение степной гадюки на Правобережье через Нижнеднепровские пески, которые, по мнению некоторых географов [5], в конце плейстоцена находились на правом, а не на левом, как в настоящее время, берегу Днепра, и в периоды морских регрессий, при освобождении от воды территории Каркинитского залива граничили с Крымом [14; 17]. Отсюда гадюки при постепенных трансформациях дельтовой системы Днепра и Буга и последовательном отмирании части палеорусел могли бы расселиться в западном (например, по приморским пескам) и северном (по речным долинам) направлениях и занять значительную часть Правобережья.

Следует отметить также, что уровень морфологических отличий между всеми изученными популяциями невысок по сравнению с подвидами обыкновенной гадюки. Даже наиболее своеобразные популяции хуже дифференцированы, а наибольший вклад в разделение популяций в пространстве корней канонической функции имеют признаки щиткования головы (см. табл. 3). В случае обыкновенной гадюки эти признаки в анализе, как правило, имели второстепенное значение для разделения подвидов и скорее относились к внутриподвидовой популяционной изменчивости. На наш взгляд, это свидетельствует о менее выраженной экологической специализации и возможно меньшем генетическом расстоянии и времени дивергенции изученных популяций степной гадюки по сравнению с подвидами обыкновенной гадюки. И наоборот, потенциально высокоадаптивные признаки, связанные с размером и пропорциями тела (Ventr., S. cd., Sq.) или размерами потенциальной добычи и биомеханикой процесса заглатывания (Lab., Sub.), показывают незначительный вклад в дискриминантную функцию (табл. 3).

Сходство V. renardi из Сасовки с крымскими змеями, с одной стороны, и почти полное перекрывание кировоградской выборки самцов с двумя левобережными - с другой, может указывать как на сложную историю популяций и возможность заселения Правобережья гадюками из разных источников, так и на влияние природных условий (прежде всего, климатических параметров) на морфологию популяций [25].

Следует также добавить, что степная балка в близ с. Сасовка Компанеевского р-на Кировоградской обл. заслуживает придания ей охранного статуса как одно из немногих известных местообитаний степной гадюки - вида, внесенного в Красную книгу Украины [12] - в Правобережной Украине. Кроме V. renardi, здесь отмечены и другие краснокнижные виды [6], а в 2008 г. отмечена степная мышовка Sicista subtilis (Pallas, 1773) (неопубликованные данные А. И. Зиненко). 


\section{Выводы}

Степная гадюка в Кировоградской области представлена подвидом $V$. r. renardi и демонстрирует морфологическое сходство с популяциями из Восточной и СевероВосточной Украины; самки также сходны с равнинными крымскими и присивашскими популяциями. Уровень морфологических отличий между популяциями степной гадюки в Украине ниже, чем между подвидами обыкновенной гадюки, что может быть связано с отсутствием экологической специализации у популяций, небольшим временем их дивергенции или сложной историей расселения и взаимодействием популяций. Граница между V. renardi и V. ursinii проходит западнее Днепра, который не является западной границей ареала восточной степной гадюки. Изученная популяция степной гадюки заслуживает охраны как одна из немногих сохранившихся на Правобережье.

\section{Библиографические ссылки}

1. Барабаш-Никифоров І. І. Нариси фауни степової Наддніпрянщини (колишньої Катеринославщини). - Ч. 1. Загальний огляд природи. Ч. 2. Фауна краю. - Д. : Держ. вид-во України, 1928. - 137 с.

2. Браунер А. Предварительное сообщение о пресмыкающихся и гадах Бессарабии, Херсонской губернии, Крыма и Северо-Западного Кавказа между Новороссийском и Адлером // Записки Новороссийского о-ва естествоиспытателей. - Одесса : Тип. А. Шульца, 1903. - Т. 25, вып. 1. - С. 43-59.

3. Булахов В. Л. Біологічне різноманіття України. Дніпропетровська область. Земноводні та плазуни / В. Л. Булахов, В. Я. Гассо, О. С. Пахомов. - Д. : ДНУ, 2007. - 420 с.

4. Волянський Б. Земноводяні та плазуни околиць міста Одеси. Етюди щодо ойкології та економічного значення // Зап. прир.-мат. секц. Одес. наук. т-ва при Укр. АН. - Одеса : Одесполиграф, 1928. - С. 75-109.

5. Гордиенко И. Олешковские пески и биоценотические связи в процессе их зарастания. - К. : Наукова думка, 1969. - 245 с.

6. Гулай В. В. Значення військових полігонів у збереженні раритетних видів тварин України // Биоразнообразие и роль зооценоза в естественных и антропогенных экосистемах. Матер. II Междунар. научн. конф. - Д. : ДНУ, 2003. - С. 202-203.

7. Доценко И. Б. Герпетофауна антропогенных ландшафтов Николаевской и Одесской областей / И. Б. Доценко, В. И. Радченко // Зб. пр. Зоологічного музею. - 2005. - № 37. - С. 109-120.

8. Котенко Т. И. Темпы роста и линька степной гадюки на Украине // Вестник зоологии. - 1989. № 3. - С. 55-58.

9. Котенко Т. И. О распространении степной гадюки, Vipera renardi (Reptilia, Viperidae), в западной части равнинного Крыма // Вестник зоологии. - 2007. - Т. 41, № 5. - С. 422.

10. Котенко Т. И. Роль Азово-Черноморского функционального экокоридора в сохранении пресмыкающихся // Наук. вісн. Ужгород. ун-ту. Серія: Біологія. - 2007. - Вип. 21. - С. 20-54.

11. Котенко Т. І. Гадюка степова, Vipera renardi (Christ.), - вид Червоної книги України / Т. I. Котенко, О. В. Кукушкін // Знахідки тварин Червоної книги України. - К., 2008. - С. 101-132.

12. Котенко Т. І. Гадюка степова Vipera renardi Christoph, 1861 / Т. І. Котенко, О. В. Кукушкін // Червона книга України. Тваринний світ / за ред. І. А. Акімова. - К. : Глобалконсалтинг, 2009. - С. 397.

13. Кукушкин О. В. Vipera renardi puzanovi ssp. nov. (Reptilia, Serpentes, Viperidae) - новый подвид степной гадюки из Горного Крыма // Современная герпетология. -2009. - Т. 9, вып. 1/2. - С. 18 - 40.

14. Мельник В. И. Влияние речной сети суши на рельеф и осадконакопление в Черном море // Экологическая безопасность прибрежной и шельфовой зон и комплексное использование ресурсов шельфа. - Севастополь : МГИ НАНУ, 2001. - Вып. 4. - С. 112-124.

15. Никитенко М. Пресмыкающиеся Советской Буковины // Животный мир Советской Буковины. Черновцы, 1959. - С. 134-160.

16. Никольский А. М. Фауна России и сопредельных стран. Пресмыкающиеся (Reptilia). - Петроград, 1916. - Т. 2: Ophidia. -350 c. 
17. Палеогеография Европы за последние сто тысяч лет. Атлас / Н. Благоволин, О. Леонтьев, В. Муратов и др. - М. : Наука, 1982.

18. Таращук С. В. Степная гадюка в правобережной степи Украины // Вестник зоологии. - 1985. № 4. - C. 80-81.

19. Цемш І. О. До систематики та географічного поширення амфібій та рептилій на Україні // Студентські наук. пр. Київ. держ. ун-ту ім. Т. Г. Шевченка. - 1939. - № 4. - С. 103-117.

20. Цуркану В. Ф. Формирование и современное распространение фауны змей ДнестровскоПрутского междуречья // Buletinul ştiinţific al Muzeului Naţional de Etnografie şi Istorie Naturală. Vol. 2 (15). - Chişinău, 2005. - P. 63-68.

21. Шарлемань М. В. Зоогеографія УРСР. Матеріали до вивчення географічного поширення наземних хребетних УРСР. - К. : Вид-во АН УРСР, 1937. - 253 с.

22. Godinho R. The limits of mt DNA phylogeography: Complex patterns of population history in a highly structured Iberian lizard are only revealed by the use of nuclear markers / R. Godinho, E. G. Crespo, N. Ferrand // Molecular Ecology. - 2008. - Vol. 17. - P. 4670-4683.

23. Krecsak L. An updated overview of the distribution of the moldavian steppe viper (Vipera ursinii moldavica Nilson, Andren et Joger, 1993) / L. Krecsak, S. Zamifrescu, Z. Korsos // Russian Journal of Zoology. - 2003. - Vol. 10, N 3. - P. 195-206.

24. Krecsak L. Vipera (Acridophaga) ursinii in Romania: Historical and present distribution / L. Krecsak, S. Zamifrescu // North-Western Journal of Zoology. - 2008. - Vol. 4, N 2. - P. 339-359.

25. Kukushkin O. Morphological peculiarities and their possible bearing on the taxonomic status of the Crimean montane populations of the Steppe viper, Vipera renardi Christoph, 1861 / O. V. Kukushkin, O. I. Zinenko // M. Vences, J. Kohler, T. Ziegler, W. Bohme (eds.): Herpetologia Bonnensis II. Proceedings of the 13th Congress of the Societas Europaea Herpetologica. - Bonn, 2006. - P. 61-66.

26. Mehely L. Systematisch-phylogenetische studien an Viperiden // Annals Musei Nationalis Hungarici. 1911. - Vol. 9. - S. 186-243.

27. Nilson G. A re-evaluation of the taxonomic status of the moldavian steppe viper based on immunological investigations, with a discussion of the intergradation between Vipera ursinii racosiensis and Vipera (ursinii) renardi / G. Nilson, C. Andren, U. Joger // Amphibia-Reptilia. - 1993. - Vol. 14. - P. 45-57.

28. Nilson G. The meadow and steppe vipers of Europe and Asia: The Vipera (Acridophaga) ursinii complex / G. Nilson, C. Andren // Acta Zoologica Academiae Hungaricae. - 2001. - Vol. 47, N 2-3. - P. 87-267.

29. Patrick D. Venomous snakes of Europe, Northern, Central and Western Asia / D. Patrick, G. Vogel // Terralog. - Vol. 16. - Frankfurt am Main: Chimaira, 2009. - P. 160.

30. Sos T. Review of recent taxonomic and nomenclature changes in European Amphibia and Reptilia related to Romanian herpetofauna // Herpetologica Romanica. - 2008. - Vol. 2. - P. 61-91.

31. Speybroeck J. Species list of the European herpetofauna - A tentative update / J. Speybroeck, P.-A. Crochet // Pod@rcis. - 2007. - Vol. 8, N 1/2. - P. 8-34.

32. William J. The incomplete natural history of mitochondria / J. William, O. Ballard, M. C. Whitlock // Molecular Ecology. - 2004. - Vol. 13. - P. 729-744.

33. Zinenko O. Distribution and morphological variation of Vipera berus nikolskii Vedmederja, Grubant et Rudaeva, 1986 in Western Ukraine, Republic of Moldova and Romania / O. Zinenko, V. Ţurcanu, A. Strugariu // Amphibia-Reptilia. - 2010. - Vol. 31. - P. 51-67.

Надійшла до редколегії 25.07.2011 